\title{
PENGGUNAAN MEDIA AUDIO VISUAL UNTUK MENINGKATKAN KETERAMPILAN MENULIS PERMULAAN PADA ANAK KELOMPOK B TK PERTIWI I KOTA JAMBI
}

\author{
YURMAIDA \\ TK Buah Hati Kota Jambi \\ Email: mayurmaida10@gmail.com
}

\begin{abstract}
ABSTRAK
Kemampuan menulis pada anak usia dini merupakan komponen penting dalam pengembangan keaksaraan anak serta dapat digunakan sebagai prediksi dari keterlambatan membaca. Kenyataan yang penulis temukan di lapangan yaitu di TK Pertiwi I Kota Jambi kelompok B bahwa: 1) masih banyak siswa yang belum memiliki keterampilan menulis secara efektif, 2) siswa merasa cepat bosan dalam aktifitas menulis, 3) beberapa anak kesulitan dalam mengikuti pembelajaran menulis.

Penelitian ini menggunakan jenis penelitian tindakan kelas. Dalam pelaksanaannya penelitian ini terbagi atas 2 siklus yaitu siklus I, dan siklus II. Hasil penelitian menunjukkan bahwa dengan menggunakan media audio visual dapat meningkatkan keterampilan menulis permulaan pada anak kelompok B TK Buah Hati Kota Jambi. Hal ini ditunjukkan dengan presentase ketuntasan klasikal kondisi awal ketuntasan anak mencapai 40\%, siklus I mencapai 66\% dan siklus II mencapai $83 \%$.
\end{abstract}

\section{Kata Kunci: Media Audio Visual, Keterampilan Menulis Permulaan}

\section{A. PENDAHULUAN}

\section{Latar Belakang Masalah}

Taman kanak-kanak merupakan salah satu bentuk satuan pendidikan anak usia dini pada jalur pendidikan formal yang menyelenggarakan program pendidikan bagi anak usia empat tahun sampai enam tahun. Taman kanak-kanak membantu anak didik mengembangkan berbagai potensi baik psikis maupun fisik untuk siap memasuki pendidikan dasar. Tugas utama TK adalah mempersiapkan anak dengan memperkenalkan berbagai pengetahuan, sikap atau prilaku, dan keterampilan agar anak dapat melanjutkan kegiatan sesungguhnya di sekolah dasar. Di samping itu, TK merupakan tempat yang menyenangkan bagi anakanak. 
Salah satu bidang kemampuan dasar yang harus dipersiapkan oleh guru adalah keterampilan menulis. Keterampilan menulis sejak dini sangat penting bagi anak, melalui sebuah tulisan anak dapat mengungkapkan sesuatu hal yang ditujukan kepada orang yang ada di sekitarnya. Selain itu, keterampilan menulis membantu anak agar memiliki kesiapan dalam memasuki pendidikan lebih lanjut. Mulyono mengungkapkan bahwa sejak masuk sekolah dasar, anak harus belajar menulis tangan karena kemampuan ini merupakan prasyarat bagi bidang studi yang lain. Kesulitan menulis dengan tangan tidak hanya menimbulkan masalah bagi anak tetapi juga guru. ${ }^{1}$

Menulis bagi anak usia dini diartikan sebagai suatu kegiatan membuat pola atau menuliskan kata-kata, huruf-huruf atau pun simbol-simbol pada suatu permukaan dengan memotong, mengukur atau menandai dengan pena. Kegunaan menulis bagi para siswa adalah untuk menyalin, mencatat dan mengerjakan sebagian tugas sekolah. Tanpa memiliki kemampuan menulis, siswa akan mengalami banyak kesulitan dalam melaksanakan tugas tersebut.

Tahapan kemampuan menulis anak usia dini menurut Jamaris dalam Susanto terdiri dari lima bagian, yaitu: 1) tahap mencoret (usia 2,5-3 tahun), 2) tahap pengulangan secara linier (usia 4 tahun), 3) tahap menulis secara acak (usia 4-5 tahun), 4) tahap menulis tulisan nama (usia 5,5 tahun), dan 5) tahap menulis kalimat pendek (usia di atas 5 tahun). ${ }^{2}$

Tahapan perkembangan menulis tersebut dapat berkembang secara baik apabila kegiatan menulis dapat dilakukan dengan anak atas keinginan sendiri. Adapun prinsip-prinsip yang perlu diperhatikan dalam menumbuhkan keinginan menulis anak menurut Depdiknas di antaranya adalah:

1. Prinsip penggunaan tanda atau simbol: guru memberikan kesempatan yang banyak pada anak untuk melatih kelenturan motorik halus anak.

2. Prinsip pengulangan: memberikan latihan pengulangan.

3. Prinsip keluwesan: guru memperkenalkan tulisan pertama kali pada anak berupa simbol atau tanda yang dekat dan dikenal anak.

\footnotetext{
${ }^{1}$ Mulyono, Pendidikan Bagi Anak Berkesulitan Belajar, (Jakarta: Rineka Cipta, 1999), hal. 227.

${ }^{2}$ Ahmad Susanto, Perkembangan Anak Usia Dini, (Jakarta: Prenada Media Group, 2011), hal. 92.
} 
4. Prinsip pengungkapan: memberikan kesempatan pada anak untuk mengungkapkan berbagai pengalamannya berkaitan dengan tulisan yang telah dibuatnya.

5. Prinsip mencontoh: guru sering mengulang berbagai contoh tulisan atau kata dengan konteks yang sama.

6. Prinsip penguatan: guru memberikan penguatan berupa penghargaan atau pujian terhadap hasil tulisan anak.

Kemampuan menulis pada anak usia dini merupakan komponen penting dalam pengembangan keaksaraan anak serta dapat digunakan sebagai prediksi dari keterlambatan membaca. Santrock mengatakan bahwa keahlian motorik halus anak usia dini lazimnya berkembang sedemikian rupa sehingga mereka mulai sanggup menulis huruf-huruf pada masa awal kanak-kanak mereka.

Kenyataan yang penulis temukan di lapangan yaitu di TK Pertiwi I Kota Jambi kelompok B bahwa: 1) masih banyak siswa yang belum memiliki keterampilan menulis secara efektif, 2) siswa merasa cepat bosan dalam aktifitas menulis, 3) beberapa anak kesulitan dalam mengikuti pembelajaran menulis.

Sehubungan dengan permasalahan di atas, salah satu upaya yang peneliti lakukan untuk meningkatkan keterampilan menulis permulaan pada siswa TK Pertiwi I Kota Jambi kelompok B adalah dengan menerapkan media pembelajaran audio visual. Media pembelajaran ini diharapkan dapat mengatasi permsalahan tersebut.

Dhieni, dkk mengartikan media audio visual adalah media yang dapat menyampaikan pesan melalui visual berupa gambar dan tulisan sekaligus juga melalui suara-suara atau bunyi yang diperdengarkan. ${ }^{3}$ Penggunaan media audio visual memudahkan anak untuk meriilkan sesuatu yang bersifat abstrak, sehingga dapat merangsang peserta didik untuk lebih berkonsentrasi dan lebih memahami materi yang diajarkan karena penyampaian materi dengan media audio visual bisa lebih jelas. Anak dapat mengamati dengan jelas tulisan serta gambar yang mereka pelajari sehingga dapat melatih kemampuan mengenal huruf dan kata. ${ }^{3}$ Dhieni, dkk, Materi Pokok Metode Pengembangan Bahasa, (Jakarta: Universitas Terbuka, 2009),
hal. 31. 
Seperti umumnya media sejenis media audio visual mempunyai tingkat efektifitas yang cukup tinggi, menurut riset, rata-rata di atas $60 \%$ sampai $80 \%$. Pengajaran melalui audio visual jelas bercirikan pemakaian perangkat keras selama proses belajar, seperti mesin proyektor film, televisi, tape recorder dan proyektor visual yang lebar. ${ }^{4}$

Kemampuan media audio visual dianggap lebih baik dan lebih menarik, sebab mengandung kedua unsur jenis media yang pertama dan kedua. Selain itu, media audio visual memberikan kesan positif yaitu lebih menarik, lebih menyenangkan dan memberi memori yang kuat. Pelaksanaan kegiatan yang mengasyikkan dan menarik minat anak dapat membantu perkembangan anak secara optimal.

Media audio visual merupakan salah satu solusi yang penulis tawarkan dalam meningkatkan keterampilan menulis permulaan pada anak kelompok B TK Pertiwi I Kota Jambi dengan judul: Penggunaan Media Audio Visual Untuk Meningkatkan Keterampilan Menulis Permulaan Pada Anak Kelompok B TK Pertiwi I Kota Jambi.

\section{Rumusan Masalah}

Adapun rumusan masalah dalam penelitian ini adalah: apakah penggunaan media audio visual dapat Meningkatkan Keterampilan Menulis Permulaan Pada Anak Kelompok B TK Pertiwi I Kota Jambi?

\section{Tujuan Penelitian}

Sesuai dengan pernyataan yang diajukan dalam rumusan masalah di atas, maka tujuan yang ingin dicapai melalui pembahasan ini adalah untuk mengetahui apakah penggunaan media audio visual dapat meningkatkan keterampilan menulis permulaan pada anak kelompok B TK Pertiwi I Kota Jambi.

\footnotetext{
${ }^{4}$ Azhar Arsyad, Media Pembelajaran, (Jakarta: PT. Raja Grafindo Persada, 2013), hal. 30
} 


\section{Manfaat Penelitian}

Manfaat dari penelitian tindakan ini adalah:

\section{Bagi Siswa}
a. Untuk meningkatkan keterampilan menulis permulaan bagi siswa
b. Agar murid aktif dan respon terhadap pembelajaran menulis permulaan.
c. Untuk mengaktifkan dan mengembangkan minat belajar siswa.

\section{Bagi Guru}

a. Meningkatkan kinerja guru yang profesional

b. Memberikan wawasan tentang penggunaan media audio visual dalam pembelajaran

c. Sebagai dasar untuk mengembangkan teknik pembelajaran dan kreativitas guru dalam menemukan media yang sesuai dengan tujuan dan materi yang akan diberikan sehingga apa yang diharapkan oleh guru dapat tercapai.

\section{Bagi Sekolah}

Sebagai masukan bagi peningkatan pembelajaran yang kreatif dan inovatif di taman kanak-kanak serta peningkatan proses belajar mengajar sesuai kurikulum TK dan sebagai bahan pertimbangan dalam menyusun program pembelajaran serta menentukan media pembelajaran yang tepat untuk meningkatkan keterampilan menulis permulaan pada anak usia dini.

\section{B. KAJIAN TEORI}

\section{Media Pembelajaran}

\section{1) Pengertian Media Pembelajaran}

Menurut Association of Education and Communication Technology (AECT), media adalah segala bentuk dan saluran yang digunakan untuk menyalurkan pesan atau informasi. ${ }^{5}$ Menurut Anderson yang dikutip oleh Bambang Warsita $^{6}$ media dapat dibagi dalam dua kategori, yaitu alat bantu pembelajaran dan media pembelajaran. alat bantu pembelajaran disebut juga alat

\footnotetext{
${ }^{5}$ Hamzah, Nina Lamatenggo, Teknologi Komunikasi \& Informasi Pembelajaran (Jakarta: PT. Bumi Aksara, 2011), hal. 121.

${ }^{6}$ Bambang Warsita, 2008, hal. 123
} 
bantu mengajar. Misalnya OHP, film, model benda, dan lain sebagainya untuk memperjelas materi pembelajaran.

Media pembelajaran adalah segala bentuk alat komunikasi yang dapat digunakan untuk menyampaikan informasi dari sumber ke peserta didik secara terencana sehingga tercipta lingkungan belajar yang kondusif di mana penerimanya dapat melakukan proses belajar secara efektif dan efisien. ${ }^{7}$ Menurut Rusman, media pembelajaran merupakan suatu teknologi pembawa pesan yang dapat digunakan untuk keperluan pembelajaran, media pembelajaran merupakan sarana fisik untuk menyampaikan materi pelajaran. Media pembelajaran merupakan sarana komunikasi dalam bentuk cetak maupun pandang dan dengar termasuk teknologi perangkat keras. ${ }^{8}$

Dalam proses belajar mengajar kehadiran media mempunyai arti yang cukup penting. Karena dalam kegiatan tersebut ketidakjelasan bahan yang disampaikan dapat dibantu dengan menghadirkan media sebagai perantara. Media berperan penting dalam proses belajar mengajar, guru harus mampu mengoperasikan media dan penggunaan media juga bisa menjadi alternative dalam belajar, sebagai bentuk meningkatkan mutu belajar dan tercapainya tujuan belajar. $^{9}$

Berdasarkan pendapat di atas dapat disimpulkan, media pembelajaran adalah alat bantu yang digunakan oleh pendidik dalam proses pembelajaran sehingga akan lebih menarik perhatian peserta didik. Media pembelajaran juga mampu menjembatani pendidik untuk membuat pembelajaran menjadi lebih bermakna.

\section{2) Manfaat Media Pembelajaran}

Secara umum, manfaat media dalam proses pembelajaran adalah memperlancar interaksi antara guru dengan siswa sehingga pembelajaran menjadi

\footnotetext{
${ }^{7}$ Hamzah, Nina Lamatenggo, Op. Cit hal. 122.

${ }^{8}$ Rusman, Deni Kurniawan dan Cepi Riyana, Op. Cit h. 170.

${ }^{9}$ Sumarto Sumarto, "Peran Dan Kredibilitas Badan Akreditasi Nasional Sekolah/Madrasah (Ban S/M) Mewujudkan Sekolah Efektif Melalui Manajemen Mutu," Jurnal Literasiologi 1, no. 1 (2018): 12-12.
} 
lebih efektif dan efisien. Syaiful Bahri mengungkapkan bahwa media bermanfaat bagi peserta didik untuk memperoleh pesan dan informasi sehingga membentuk pengetahuan baru pada siswa. Dalam batas tertentu, media dapat menggantikan fungsi guru sebagai sumber informasi/pengetahuan bagi peserta didik. Media pembelajaran membawa dan membangkitkan rasa senang dan gembira serta membantu mereka untuk memantapkan pengetahuan. ${ }^{10}$

Menurut Nana Sudjana dan Ahmad Rivai, manfaat media pembelajaran adalah sebagai berikut: ${ }^{11}$

a. Pembelajaran akan lebih menarik perhatian peserta didik sehingga dapat menumbuhkan motivasi belajar.

b. Bahan pembelajaran akan lebih jelas maknanya sehingga dapat lebih dipahami oleh siswa sehingga memungkinkannya menguasai dan mencapai tujuan pembelajaran.

c. Metode mengajar akan lebih bervariasi, tidak semata-mata komunikasi verbal melalui penuturan kata-kata oleh guru, sehingga siswa tidak bosan dan guru tidak kehabisan tenaga, apalagi bila guru mengajar pada setiap jam pelajaran.

d. Siswa dapat lebih banyak melakukan kegiatan belajar sebab tidak hanya mendengarkan uraian guru, tetapi juga aktivitas lain seperti mengamati, melakukan, memamerkan, dll.

Menurut Azhar Arsyad ada beberapa manfaat praktis dari penggunaan media pembelajaran di dalam proses belajar mengajar yaitu sebagai berikut:

1. Media pembelajaran dapat memperjelas penyajian pesan dan informasi sehingga dapat memperlancar dan meningkatkan proses dan hasil belajar.

2. Media pembelajaran dapat meningkatkan dan mengarahkan perhatian anak sehingga dapat menimbulkan motivasi belajar, interaksi yang lebih langsung antara siswa dan lingkungannya, dan kemungkinan siswa untuk belajar sendirisendiri sesuai dengan kemampuan dan minatnya.

\footnotetext{
${ }^{10}$ Syaiful Bahri Djamarah Dan Aswan Zain, Strategi Belajar Mengajar, (Jakarta: PT Rineka Cipta, 2010), hal. 122

${ }^{11}$ Nana Sudjana dan Ahmad Rivai, Media Pengajaran, (Bandung: Sinar Baru Algensindo, 2002), hal. 2
} 
3. Media pembelajaran dapat mengatasi keterbatasan indera, ruang, dan waktu. Misal: objek yang terlalu besar untuk ditampilkan langsung di ruang kelas dapat diganti dengan gambar, foto, slide, dan sebagainya.

4. Media pembelajaran dapat memberikan kesamaan pengalaman kepada siswa tentang peristiwa-peristiwa di lingkungan mereka, serta memungkinkan terjadinya interaksi langsung dengan guru. ${ }^{12}$

\section{3) Macam-Macam Media Pembelajaran}

Media Pembelajaran mempunyai jenis yang beragam, mulai dari yang sederhana hingga yang canggih. Ada yang dibuat sendiri oleh guru yang bersangkutan dan ada pula yang diproduksi oleh pabrik. Ada media yang sudah tersedia di lingkungan sekitar, ada pula yang sengaja dirancang untuk pembelajaran. Meskipun begitu, tidak semua jenis media pembelajaran dapat dimanfaatkan oleh guru. Media pembelajaran yang biasa dimanfaatkan adalah media cetak, misalnya buku. Selain itu, juga terdapat sekolah yang telah memanfaatkan media lain, seperti gambar, OHP, slide, dan sebagainya.

Berdasarkan rancangannya, media pembelajaran dapat dibagi menjadi dua jenis, yaitu:

1. Media yang dirancang, yaitu media dan sumber belajar yang secara khusus dirancang atau dikembangkan oleh pendidik sebagai komponen pada sistem pembelajaran untuk memberikan fasilitas belajar yang terarah kepada peserta didik dan bersifat formal.

2. Media yang dimanfaatkan, yaitu media dan sumber belajar yang tidak didesain khusus oleh pendidik untuk keperluan pembelajaran dan keberadaannya dapat ditemukan, diterapkan dan dimanfaatkan untuk keperluan pembelajaran, misalnya kebun binatang untuk mengajarkan kepada peserta didik tentang macam-macam hewan.

Menurut Syaiful Bahri, media pembelajaran dibagi menjadi 3 macam, yaitu: ${ }^{13}$

${ }^{12}$ Azhar Rasyad, Media Pengajaran , (Jakarta: RajaGrafindo Persada, 1997), hal. 26-27. 
1. Media auditif, adalah media yang hanya mengandalkan kemampuan suara saja, seperti radio.

2. Media visual, adalah media yang hanya mengandalkan indra penglihatan.

3. Media audio visual, adalah media yang mempunyai unsur suara dan unsur gambar.

\section{Media Pembelajaran Audio Visual}

Media audio-visual merupakan media pembelajaran yang digunakan guru untuk menyampaikan materi agar diterima siswa melalui indera pendengar dan penglihat secara terpadu. Media audio-visual ini termasuk jenis media yang berbasis indera penyerap. Media audio-visual mencakup siaran TV, rekaman VCD, dan pentas drama atau sandiwara.

Menurut Ahmad Rohani dalam bukunya, bahwa media audio-visual merupakan media instruksional modern yang sesuai dengan perkembangan zaman (kemajuan ilmu pengetahuan dan teknologi) yang meliputi media yang dapat dilihat, didengar, dan yang dapat didengar dan dilihat, sebagaimana berikut ini: ${ }^{14}$

1. Film

Film adalah salah satu jenis media audio visual. Dibanding dengan media yang lain, film mempunyai kelebihan sebagai berikut:

- Penerima pesan akan mudah memperoleh tanggapan yang lebih jelas dan tidak mudah dilupakan, karena antara melihat dan mendengar dapat dikombinasikan menjadi satu.

- Dapat menikmati kejadian dalam waktu yang lama pada suatu proses atau peristiwa tertentu.

- Dengan teknik slow-motion dapat mengikuti suatu gerakan atau aktivitas yang berlangsung cepat.

- Dapat mengatasi keterbatasan ruang dan waktu

- Dapat membangun sikap, perbuatan, dan membangkitkan emosi dan mengembangkan problema.

${ }^{13}$ Syaiful Bahri, Op.Cit, hal. 124

${ }^{14}$ Ahmad Rohani, Op. Cit, hal. 54 


\section{Televisi}

TV merupakan media yang ampuh dalam menyebarkan informasi secara serempak, dan telah terbukti memiliki kemampuan yang sangat efektif (penetrasinya lebih dari 70\%), sehingga bisa dimanfaatkan untuk penyiaran program-program pembelajaran secara nasional.

\section{Keterampilan Menulis Permulaan}

Menurut Chaplin, ${ }^{15}$ keterampilan adalah kemampuan bertingkat tinggi yang memungkinkan seseorang melakukan satu perbuatan yang kompleks. Masitoh berpendapat bahwa keterampilan adalah gerakan yang memerlukan koordinasi dan control gerak yang cukup kompleks, berdasarkan derajat kesukarannya bisa diklasifikasikan menjadi keterampilan sederhana, terpadu dan kompleks.

Menurut Nuruddin menulis adalah kegiatan yang dilakukan seseorang untuk menghasilkan tulisan. Sedangkan Badudu di dalam Dhieni, ${ }^{16}$ mengemukakan bahwa menulis adalah menggunakan pena, ball point di atas kertas, kain ataupun papan yang menghasilkan huruf, kata maupun kalimat. Sedangkan keterampilan menulis permulaan mengandung tiga dimensi berikut: komposisi, tulisan tangan, dan ejaan. Komposisi yang dimaksud adalah bagaimana anak terlibat dalam proses penulisan dan menghasilkan gagasan mereka untuk menulis. Tulisan tangan difokuskan pada formasi huruf, seperti membahas bentuk huruf dan menulis huruf. Ejaan difokuskan pada ortografi, yaitu mengenali bahwa huruf mewakili suara dan mampu untuk mengidentifikasi dan menulis apa yang diucapkannya menjadi sebuah kata.

Kemampuan menulis pada anak usia dini merupakan komponen penting dalam pengembangan keaksaraan anak serta dapat digunakan sebagai prediksi dari keterlambatan membaca. Sedangkan yang dimaksud dengan kemampuan menulis bagi anak usia dini menurut Karli diartikan sebagai suatu kegiatan membuat pola atau menuliskan kata, huruf-huruf atau pun simbol-simbol pada suatu permukaan.

${ }^{15}$ Chaplin, Kamus Lengkap Psikologi (Penerj. Kartini Kartono), (Jakarta: PT. Raja Grafindo Persada, 2002), hal. 465

${ }^{16}$ Dhieni, Op. Cit, hal, 10 
Dari beberapa pengertian di atas dapat diambil kesimpulan bahwa kemampuan menulis permulaan bagi anak usia dini adalah kemampuan dalam menulis simbol huruf yang telah diketahuinya, menulis sebuah kata, dan mengeja apa yang telah ditulis.

Empat tahapan dalam menulis permulaan pada anak usia dini yaitu sebagai berikut:

\section{a. Scribbling stage}

Tahap di mana anak dengan ciri menulis dimulai dengan mencoret, coretan hanya memberi tanda acak pada kertas. Anak mulai membentuk beberapa garis (dari atas ke bawah) seperti menulis dan berisi bagian utama coretan di dalam kotak. Coretan ini mengidentifikasikan kemampuan anak dalam mengontrol alat tulis dan peningkatan pengetahuannya terhadap bentuk kertas.

Menurut Brewer stimulasi yang dapat dilakukan pada tahap ini yaitu menyediakan berbagai jenis bahan seperti cat, buku, kertas dan krayon. Pendidik harus memberi lebel pada coretan anak sebagai tulisan, menjadi model untuk menulis dalam berbagai kesempatan di hadapan anak.

\section{b. Linear repetitive stage}

Tahap ini ditandai dengan anak mulai menulis biasanya dalam bentuk garis horizontal dan huruf-huruf yang terpisah-pisah dalam buku bergaris. Anak dapat melihat hubungan kongkret antara kata-kata dan bentuknya. Orang dewasa dapat memberi contoh menulis pada anak dan memberi kesempatan anak untuk mengamati tentang tulisan yang digunakan dengan berbagai jalan, memberi dukungan pada coretan anak, dan mulai memperlihatkan bentuk permulaan huruf pada anak.

\section{c. Random letter stage}

Tahap ketiga ini anak belajar bahwa bentuk-bentuk dapat dikatakan sebagai huruf. Anak dapat menggunakannya secara acak untuk menyampaikan kata atau kalimat pada orang lain. Kadang kala anak memproduksi garis huruf yang tidak sesuai dengan suara dari kata yang ditulisnya karena ingatan akan bentuk huruf pada anak sangat terbatas. Pada tahap ini, anak membuat huruf yang 
ia kenal (biasanya huruf-huruf dalam namanya) secara acak untuk menyampaikan maksud pada orang lain.

\section{d. Letter name or phoenetic wriitng}

Pada tahap ini anak mulai membuat hubungan antara huruf dan suara. Permulaan tahap ini disebut sebagai letter name writing karena anak menulis huruf dengan nama dan bunyinya sama. Misalnya, anak menulis "untuk" dengan "u". Anak mencoba untuk menampilkan kata dengan bentuk huruf yang tepat seperti yang didengar. Dan di akhir tahap, anak lebih ahli menulis dengan berbagai bentuk, seperti mahir dalam memberi jarak dalam kata. Namun ejaan yang tertulis masih berbentuk sesuai dnegan bunyinya, misalnya "ember" ditulis "mbr". Anak membutuhan waktu untuk berlatih menulis dan membaca kembali tulisannya, maka tulisannya akan lengkap sesuai dnegan ejaannya.

Menurut Cole terdapat lima tahapan kemampuan menulis permulaan yaitu:

a. Tahap mencoret (usia 2,5 sampai dengan 3 tahun)

Anak mulai belajar tentang bahasa tulisan.

b. Tahap pengulangan secara linier (usia 4 tahun)

Anak berpikir bahwa suatu kata merujuk pada sesuatu yang besar dan mempunyai tali yang panjang.

c. Tahap menulis secara acak (usia 4 sampai dengan 5 tahun)

Anak sudah dapat mengubah tulisan menjadi kata yang mengandung pesan

d. Tahap menulis tulisan nama (usia 5,5 tahun)

Pada fase ini berbagai kata yang mengandung akhiran yang sama mulia dihadirkan dengan kata dan tulisan

e. Tahap menulis kalimat pendek (usia di atas 5 tahun)

Menulis kalimat yang ditulis oleh anak dapat mengembangkan kemampuan menulis apabila kegiatan menulis dilakukan anak atas keinginan sendiri.

Dari dua pendapat di atas dapat disimpulkan bahwa tahapan menulis permulaan pada anak usia dini adalah menulis dan menghubungkan huruf-huruf dari namanya sendiri. Di saat menulis, anak dapat mengeja huruf-huruf yang sedang ditulisnya. 


\section{HASIL PENELITIAN DAN PEMBAHASAN}

\section{Hasil Penelitian}

Penelitian tindakan kelas ini dilaksana di kelas B TK Pertiwi I Kota Jambi. Penelitian tindakan kelas ini dilakukan dalam 2 siklus untuk menentukan bagaimana cara meningkatkan keterampilan menulis permulaan pada TK Pertiwi I kota Jambi kelas B. Berdasarkan penelitian yang dilaksanakan, mulai dari pemeriksaan tahap studi awal sampai pada siklus kedua diperoleh data sebagai berikut:

\section{a. Deskripsi Tahap Studi Awal}

Data yang diperoleh dari hasil observasi di kelas B TK Pertiwi I Kota Jambi bahwa masih ada beberapa siswa yang mengalami kesulitan dalam mengenal huruf dan menuliskannya dalam bentuk kata. Hal tersebut menyebabkan hasil belajar siswa mengenai keterampilan menulis permulaan tidak mencapai target sesuai dengan indikator yang diharapkan.

Berdasarkan pengamatan yang telah dilakukan, peneliti melakukan tes awal, sebelum tindakan dan diperoleh data sebagai berikut: dari 20 anak yang ada di kelas B, hanya 8 orang yang mendapatkan nilai tuntas, sementara 12 orang anak mendapatkan nilai tidak tuntas. Berdasarkan data yang diperoleh menunjukkan bahwa masih banyak anak yang mendapatkan nilai di bawah kriteria tuntas dan belum sesuai dengan indikator yang diharapkan yaitu 12 orang anak belum mencapai ketuntasan dan hal ini menunjukkan bahwa pengenalan keterampilan menulis permulaan pada anak kelompok B TK Pertiwi I Kota Jambi masih rendah.

\section{b. Deskripsi Hasil Tindakan Tiap Siklus}

Penelitian yang dilakukan adalah untuk mengatasi permasalahan yang dialami kelompok B TK Pertiwi I Kota Jambi. Permasalahan tersebut adalah rendahnya keterampilan menulis permulaan pada anak kelompok B TK Pertiwi I Kota Jambi. Tindakan yang dilakukan oleh peneliti terdiri dari 2 siklus dengan masing-masing pertemuan tiap siklusnya adalah 3 kali pertemuan. Setiap pertemuan berlangsung selama 120 menit mulai dari pukul 07.30-10.00 WIB, 
yang terbagi menjadi tiga bagian kegiatan yaitu kegiatan awal (30 menit), kegiatan inti (60 menit) dan kegiatan akhir (30 menit). Masing-masing siklus meliputi 4 tahap kegiatan yaitu perencanaan, tindakan, pengamatan, dan refleksi.

1. Pelaksanaan Siklus 1

a. Perencanaan

Adapun rangkaian perencanaan sebelum pelaksanaan tindakan diuraikan sebagai berikut:

1. Mengkondisikan lingkungan belajar atau kelas untuk menciptakan lingkungan yang kondusif dan nyaman selama kegiatan belajar berlangsung.

2. Menyiapkan RKH yang dilakukan dengan memilih indikator dan tujuan pembelajaran kaitannya dengan kegiatan keterampilan menulis permulaan yang akan dilakukan sehingga ada keterkaitan antara bidang pengembangan yang membuat ketercapaian pembelajaran seutuhnya.

3. Menyusun skenario pembelajaran sehingga keterlaksanaan kegiatan dapat berjalan dengan runtut.

4. Menyiapkan perlengkapan sarana dan prasarana yang digunakan dalam kegiatan, meliputi media dan lembar kegiatan yang digunakan. Media yang digunakan pada siklus 1 adalah media audio visual berupa laptop dan VCD.

5. Menyiapkan reward berupa stiker bergambar untuk anak yang sudah melakukan kegiatan dengan baik.

6. Menyiapkan instrumen penilaian pengenalan keterampilan menulis permulaan.

b. Tindakan

Pada tahap ini guru melaksanakan kegiatan pembelajaran pengenalan keterampilan menulis permulaan dengan media audio visual yang disusun dalam RKH. Siklus 1 dilaksanakan dengan rangkaian tiga kali pertemuan.

c. Pengamatan

Tahap ini merupakan tahap pengamatan terhadap penggunaan media audio visual dalam pengenalan keterampilan menulis permulaan. Alat atau instrumen penilaian yang digunakan berupa format penilaian yang digunakan peneliti untuk menilai dan melakukan pengamatan terhadap keterlaksanaan kegiatan. 
d. Refleksi

Kegiatan refleksi merupakan kegiatan evaluasi yang dilakukan setelah kegiatan pengamatan dan diperoleh data-data untuk dikaji dan dianalisis. Hal ini dilakukan untuk mengetahui kendala-kendala yang ditemukan dalam pelaksanaan siklus I yang kemudian akan diperbaiki dan dilanjutkan ke siklus berikutnya yaitu siklus II. Meskipun pada siklus I telah memberikan peningkatan pada kegiatan menulis permulaan namun hasil yang diperoleh belum mencapai target yang diharapkan.

\section{Pelaksanaan Siklus II}

Siklus 2 dilaksanakan dalam 3 kali pertemuan, masing-masing pertemuan selama 120 menit terdiri dari kegiatan awal, kegiatan inti dan kegiatan akhir. Pelaksanaan siklus II pada tanggal 26 Oktober 2018.

\section{Pembahasan}

Berdasarkan rumusan masalah yang disebutkan, deskripsi tindakan tiap siklus dan perbandingan hasil tindakan antar siklus berikut ini akan dikemukakan pembahasan mengenai penggunaan media audio visual untuk meningkatkan pengenalan keterampilan menulis permulaan pada anak kelompok B TK Pertiwi I Kota Jambi adalah sebagai berikut:

Hasil pengamatan dan analisis data menunjukkan bahwa pengenalan keterampilan menulis permulaan anak kelompok B TK Pertiwi I Kota Jambi mengalami peningkatan. Dalam pembelajaran pengenalan keterampilan menulis permulaan anak diajarkan: 1) sikap duduk yang baik, 2) cara meletakkan buku tulis, 3) cara memegang dan membuka buku tulis, 4) cara memegang pensil, 5) gerakan menulis di udara untuk melemahkan tangan, 6) pelatihan melemahkan jari dengan mewarnai, menyalin huruf, menebalkan, dan menggambar, 7) cara menuliskan huruf dengan menggunakan jari untuk melemaskan jari.

Penilaian pengenalan keterampilan menulis permulaan terbagi menjadi beberapa indikator penilaian, yaitu 1) menulis huruf, 2) meniru menulis tulisan, 3) menulis nama, 4) menulis frasa, 5) menulis kalimat. Hal ini ditunjukkan dengan data yang menunjukkan hasil pencapaian ketuntasan anak dan nilai rata-rata yang 
dicapai. Kondisi awal ketuntasan anak mencapai 40\%, siklus I mencapai 66\% dan siklus II mencapai 83\%. Berdasarkan hasil yang dijelaskan di atas dapat diketahui bahwa penggunaan media audio visual dalam kegiatan pembelajaran dapat meningkatkan pengenalan keterampilan menulis permulaan pada anak.

Pelaksanaan kegiatan dengan media audio visual dapat membangun kondisi yang dapat membuat anak didik mampu memperoleh pengetahuan, keterampilan, membangkitkan motivasi belajar peserta didik serta pembelajaran dapat lebih dipahami. Selain itu, penggunaan media audio visual dapat meningkatkan kreativitas dan meningkatkan ingatan pada anak.

\section{Kesimpulan}

Dengan menggunakan media audio visual dalam pembelajaran keterampilan menulis permulaan menjadikan anak lebih senang dan memahami pembelajaran. Sesuai dengan rumusan masalah yang ada dalam penelitian ini, bahwa hasil dari penelitian ini dapat diambil kesimpulan sebagai berikut:

Penggunaan media audio visual dapat meningkatkan keterampilan menulis permulaan pada anak kelompok B TK Buah Hati Kota Jambi. Hal ini ditunjukkan dengan presentase ketuntasan klasikal kondisi awal ketuntasan anak mencapai $40 \%$, siklus I mencapai $66 \%$ dan siklus II mencapai $83 \%$.

\section{DAFTAR PUSTAKA}

Ahmad Susanto, Perkembangan Anak Usia Dini, Jakarta: Prenada Media Group, 2011.

Azhar Arsyad, Media Pembelajaran, Jakarta: PT. Raja Grafindo Persada, 2013.

Burhan Bungin, Metodologi Penelitian Sosial dan Ekonomi, Jakarta: Kencana Prenada Media, 2013.

Chaplin, Kamus Lengkap Psikologi (Penerj. Kartini Kartono), Jakarta: PT. Raja Grafindo Persada, 2002.

Dhieni, dkk, Materi Pokok Metode Pengembangan Bahasa, Jakarta: Universitas Terbuka, 2009.

Hamzah, Nina Lamatenggo, Teknologi Komunikasi \& Informasi Pembelajaran, Jakarta: PT. Bumi Aksara, 2011. 
Mulyono, Pendidikan Bagi Anak Berkesulitan Belajar, Jakarta: Rineka Cipta, 1999.

Nana Sudjana dan Ahmad Rivai, Media Pengajaran, Bandung: Sinar Baru Algensindo, 2002.

Oemar Hamalik, Media Pendidikan, Bandung: Citra Aditya, 1989.

Rusman, Deni Kurniawan dan Cepi Riyana, Pembelajaran Berbasis Teknologi Informasi dan Komunikasi, Jakarta: RajaGrafindo Persada, 2013.

Rubhan Masykur, Nofrizal, Muhamad Syazali, "Pengembangan Media Pembelajaran Matematika dengan Macromedia Flash". Jurnal Pendidikan Matematika, Vol. 8, No. 2, 2017 Sternbeg. R.J, Cognitive Psychology, Bellmont, Thomson Wadsworth, 2006.

Syaiful Bahri Djamarah Dan Aswan Zain, Strategi Belajar Mengajar, Jakarta: PT Rineka Cipta, 2010.

Subana, Fungsi dan Manfaat Media Pembelajaran, Jakarta: Rineka Cipta, 1998.

Sugiyono, Memahami Penelitian Kualitatif, Bandung: Alfabeta, 2008.

Suharsimi Arikunto, Prosedur Penelitian: Suatu Pendekatan Praktik, Jakarta: PT. Rineka Cipta, 2010.

Rika Ariyani, Editor Jurnal Literasiologi. Literasi Kita Indonesia. STAI Syekh Maulana Qori. Merangin Bangko.

Sumarto, Sumarto. "Peran Dan Kredibilitas Badan Akreditasi Nasional Sekolah/Madrasah (Ban S/M) Mewujudkan Sekolah Efektif Melalui Manajemen Mutu." Jurnal Literasiologi 1, no. 1 (2018): 12-12. 